\title{
Területi immobilitás mint lehetőség és perspektíva a falusi fiatalok életében ${ }^{1}$
}

\author{
LONCSÁK NOÉMI²
}

\begin{abstract}
ABSZTRAKT
A tanulmány célja feltárni és leírni azoknak az immobil fiataloknak a jellemzőit, mobilitási dimenzióit, akik 2500 fö alatti kistelepülésen élnek, és lehetőséget, perspektívát látnak saját falujukban. Külön vizsgáljuk a fiatalok szüleinek álláspontját gyermekeik mobilitása kapcsán, párhuzamokat és magyarázatokat keresve a fiatalok véleményeivel. Az eredmények további kutatások alapjául szolgálhatnak, a vizsgált célcsoportra fókuszáló elemzéseket készíthet elő. A kutatás az MTA Kiválósági Együttmúködési Program, Mobilitás Kutatási Centrum alprogramja keretében valósult meg, összesen 104 interjú képezi a kutatás alapját.
\end{abstract}

KULCSSZAVAK: immobilitás, rurális térség, falusi fiatalok, területi rögzültség, helyben maradási okok

\section{ABSTRACT}

\section{Territorial immobility as an opportunity in the life of young people in the village}

The purpose of the study is to explore and describe the characteristics, mobility dimensions of immobilized youth living in small settlements of less than 2500 people and seeing opportunities and perspectives in their own villages. We examine separately the views of parents of young people on their children's mobility, seeking parallels and explanations with their views. The results may serve as a basis for further research and may prepare analyzes focusing on the target group. The research was carried out in the framework of the MTA Excellence Cooperation Program, the Mobility Research Center, and 104 interviews form the basis of the research.

KEYWORDS: immobility, rural area, rural youth, territorial anchorage, reasons for staying

${ }^{1}$ A tanulmány megjelenését az EFOP3.6.3-VEKOP-16-2017-00007 - „Tehetségből fiatal kutató” A kutatói életpályát támogató tevékenységek a felsőoktatásban pályázatból biztosított forrás tette lehetővé.

${ }^{2}$ Doktorandusz, Debreceni Egyetem Szociológia és Társadalompolitika Doktori Program, loncsak. noemi@arts.unideb.hu 


\section{TEMATIKUS TANULMÁNYOK - KöZségekben élő immobil fiatalok}

\section{Bevezetés}

A mozgás és mozdulatlanság szociológiai értelmezése alapvető fontossággal bír. Az egyén élethelyzetén, munkaerőpiaci státuszán, életszínvonalán túl meghatározza a lokális közösségek társadalmi összetételét, jellemvonásait, a települések struktúráját, adott esetben képes előre jelezni egy adott terület fejlettségét és elmaradottságát. A vándorlások megváltoztatják a népesség eloszlását, társadalmi, demográfiai összetételét és a területek emberi erőforrásait. A társadalmi, gazdasági és politikai folyamatok a mobilitás különböző formáira szintén hatással vannak, azonban ezekre jelen értekezésben nem kívánok kitérni. A klasszikus közgazdasági elméletek szerint a mobilitási döntésekben az egyének mindenekelőtt a magasabb bér és jobb munkavállalási lehetőségek alapján hoznak döntést, míg a megszokott környezet elvesztésével járó hiányokról mint nehezen mérhető szubjektív elemekről tesznek említést ezekben az elméletekben (Hárs 2012). Egy másik nagy elméleti iskola szerint a migráció új gazdaságtana alapján a döntéshozó egység a család. A döntést nem az egyén, hanem a kockázatcsökkentés érdekében a család hozza, és nem szükségképpen az egyéni szelekció szerint legrátermettebb egyén lesz a család által delegált migráns (Stark - Bloom 1985, Massey et al. 1993).

A mobilitás kérdésével egyfajta fordított álláspontból kívánok foglalkozni: a szakirodalmak többségével ellentétben azt vizsgálom, hogy a fiatalok miért nem mobilak és miért maradtak a falvakban. Ezt a nézőpontot korábban a 90-es évek mobilitási trendjeit vizsgálva Dövényi alkalmazta. A nagy történelmi fordulatokra a népesség szinte automatikusan növekvő térbeli mobilitással reagált (Dövényi 2007), ezért rövid kitekintést teszek arra vonatkozóan, hogyan változtak a belső vándorlási trendek az elmúlt évtizedben, mi az az értelmezési közeg, amelyben a fiatalok mobilitása/immobilitása vizsgálható. Az adatok ismertetése során a 2015-ös és a 2018as Demográfiai portré eredményeit használom. A belföldi vándorlások számának 2007-től tartó csökkenése 2014-ben fordulóponthoz ért és az állandó vándorlások száma megközelítette a 215 ezret. 2016-ra olyannyira tovább emelkedett ez a szám, hogy elérte az elmúlt 16 év legmagasabb értékét. Átlagosan életünk során több mint kétszer lépünk át településhatárt lakóhelyváltás miatt, a nőknél ez 2,4 a férfiak esetében pedig 2. Nemek szerint az állandó vándorlásban részt vevők között már 1990 előtt is a nők vándorlása volt enyhén magasabb szinten, mobilitásuk valamivel intenzívebbnek tűnik később is (Dövényi 2007). 2016-ban a 15-29 éves nők belső vándorlási rátája tért el jelentősebben a férfiakétól. Korcsoportok szerint, míg a 90es években az említett 15-29 éves korcsoport mutatott a legmagasabb mobilitást, addig a 2000-es évek elejére már a 0-14 évesek valamint a 30-44 évesek, ami ebben a párhuzamban értelmezhető a kisgyermekes családok jelentősebb mobilitásaként is (Bálint - Gödri 2015). A KSH 2018-as eredményei alapján regionális szinten Budapest és Nyugat-Dunántúl tekinthető a belföldi vándorlások elsődleges célterületeinek, míg a kibocsátó területek döntően Dél-Dunántúl, Észak-Magyarország, 


\section{TEMATIKUS TANULMÁNYOK - Községekben élő immobil fiatalok}

Észak-Alföld és Dél-Alföld. Az ország hagyományos elvándorlási térségei Észak-Magyarország és Észak-Alföld. Látható egyfajta fejlettségbeli különbség a kibocsátó és a célterületek között, olyannyira, hogy a települések jövedelmi szintje és a vándorlási ráta szoros összefüggést mutat (Bálint - Obádovics 2018). A KSH adatai még azzal egészítik ki mindezt, hogy a pozitív vándorlási egyenlegú régiókban jellemzően az országos átlag feletti az egy főre jutó GDP-növekedés, míg a negatív vándorlási különbözetűeknél országos átlag alatti volt. A népesség területi redisztribúciójának az elmúlt évekre jellemző növekvő aszimmetriájára hívja fel a figyelmet a Bálint-Obádovics szerzőpáros (2018), amellyel komoly demográfiai és munkaerőpiaci problémák előfordulását jelzik, mindemellett kevés szó esik arról, hogy a helyben maradók az említett demográfiai trendek között mennyire jelentősen meghatározzák a települések jövőjét, társadalomstruktúráját és munkaerőpiaci helyzetét. Kiemelten igaz lehet ez azokon a kistelepüléseken, amelyek jövője a népesség korstruktúrája miatt alapvetően is kétséges és aggodalmakra adhat okot.

\section{A kutatás módszerei}

A kutatás az MTA Kiválósági Együttmúködési Program Mobilitás Kutatási Centrum alprogramja keretében a Debreceni Egyetemen zajlott. A kutatási terepet a jelentős vándorlási veszteségú Észak-Alföld és Észak-Magyarország régió megyéinek néhány kiválasztott kistelepülése jelenti, amelyek állandó lakosságszáma nem éri el a 2500 főt. A kutatás kvalitatív módszerrel, interjúk felvételével történt. Kétgenerációs felvételnek tekinthető, mert a 18-25 év közötti immobil fiatalokat és az ugyanabban a faluban élő szüleiket is kérdeztük a faluban maradás okainak, indítékainak komplex megismerése céljából. A félig strukturált interjúk mellett a falvakról átfogó statisztikai leírásokat készítettünk. A szülői interjúk 7 fődimenzióból állnak, tartalmazzák a településük bemutatását, történetét, mobilitási hagyományaikat. Kérdezünk a családjukról, valamint kitérünk a vándorlási-mobilitási tényezőkre és trendekre a családjukon belül. Vizsgáljuk a szülők kapcsolathálóját, a család helyzetét a településen, a gyerekek iskoláztatását, aspirációit, céljaikat, vágyaikat a saját és a gyerekük jövőjére vonatkozóan. Végezetül megkérdezzük, hogy miért maradtak a falujukban. A fiatalok interjúinak kérdései 10 fődimenzióra épültek. Az 1. és 2. dimenzió a településükre vonatkozik, ebben kitértünk a település általános bemutatására, a helyben élő fiatalok faluképének feltárása érdekében. A történeti dimenzióban rákérdeztünk a falu lakosságának mobilitási szokásaira, hagyományaira és vándorlási lehetőségeire, azok trendjeire az elmúlt évtizedekben. A harmadik, egyben legnagyobb dimenzió a család. Kérdeztünk a családtörténetről, a mobilitási jellemzőkről, mobil és immobil családtagokról, és a velük kapcsolatos véleményekről. Részletesen jellemeztettük a fiatalokkal jelenlegi családjukat, együtt élő háztartástagokat, elsősorban iskolázottságukra, foglalkozástörténetükre, társas kapcsolataikra és mobilitási 


\section{TEMATIKUS TANULMÁNYOK - Községekben élő immobil fiatalok}

jellemzőikre kérdeztünk rá. Fontos területe még ennek a dimenziónak a család megítélése, ismertsége, elismertsége, átfogóan a helyzete a kistelepülésen belül. A negyedik dimenzióban a kapcsolathálót vizsgáltuk és az ebben beazonosítható mobilitást vagy immobilitást ösztönző tényezőket. Külön figyelmet fordítottunk a társas kapcsolataikból feltárható kötelmeikre és azokra a kényszerekre, amik megtartó erőt jelenthetnek. Az 5. dimenzió az iskolai pálya és a mobilitás kapcsolata. A szülői, nagyszülői generáció iskolai karrierjét is figyelembe véve, azokra a jellemzőkre fókuszáltunk, amelyek befolyásolták a tanulmányokhoz kapcsolódó mobilitásokat. Külön vizsgáltuk a fiatalok munkatapasztalatait és közvetlen mobilitási tapasztalatait. Végezetül rákérdeztünk a fiatalok félelmeire, biztonságról alkotott elképzeléseire, valamint a céljaikra, vágyaikra, korábbi mobilitási terveikre, esetleges kudarcaikra.

A falusi fiatalok mobilitási dimenzióit vizsgálva az interjúk végén arról kérdeztük őket, hogy összességében mit gondolnak, miért maradtak a kistelepülésükön. A szubjektív mobilitás kérdése fontos kiegészítője lehet az egyéb vizsgálati dimenzióknak, értéktöbbletet hordoz, egyéni véleményeket, döntési aspektusokat, amelyeket az egyén maga számára fontos tényezőnek tart, és amik talán a többi válaszok mentén nem kerülhetnek felszínre.

A fiatalok válaszai alapján három csoport körvonalazódott, az első csoportba azok tartoznak, akik valamilyen kényszer, negatív megtartó erő miatt döntöttek a falujuk mellett. A másik csoport, amelybe a megkérdezett fiatalok többsége sorolta magát, azok, akik pusztán a „falu szeretete”, a család közelsége miatt maradtak, ők a falusi rögzült helyzetükben sem hátrányt, sem előnyt nem érzékelnek. Jelen esettanulmány a fiatalok szubjektív véleménye alapján kirajzolódó harmadik típusba tartozók helyzetét vizsgálja, akik valamiféle előnyt, lehetőséget láttak a kistelepülésükben, amikor a maradás mellett döntöttek. A továbbiakban jelen tanulmány ezeket a fiatalokat és a megkérdezett szülőket kívánja bemutatni, jellemezni, különös tekintettel mobilitásukra és döntésük okainak feltárására. A fiatalok településeinek bemutatása, majd a szülők véleményeinek leírása után az immobilitásukat lehetőségként megélő fiatalok egyéb dimenziókban adott válaszaikat, jellemzőiket vizsgálom, törekedve típusalkotásra és a magyarázó okok feltárására.

\section{A települések jellemzői}

A falvakban maradást perspektívaként megélő fiatalok települései körében a legkisebbfalu 336 fős, a legnépesebb pedig 2475 fős. Többségük hátrányos helyzetű, és jelentősebb munkanélküliséggel is sújtott. A községek megközelíthetősége nehéz, vannak közöttük kisforgalmú utak menti települések és zsákfalvak is, mindehhez párosul egy nem megfelelő tömegközlekedés, ami megnehezíti a közeli városok elérését. 


\section{TEMATIKUS TANULMÁNYOK - Községekben élő immobil fiatalok}

„Én az ő gyerekkorukból éreztem, mivel még akkor nem volt autó, mert nem engedhettük meg magunkat. Azt, hogy ök nem tudtak olyan szakkörökre lemenni vagy nem tudtam értük menni az mindig hátrány volt. Hátrány volt az is, hogy valamikor Dávid elment volna hatosztályos gimnáziumba és direkt csak azért nem tudtuk, mert így adódott, hogy buszhoz voltunk kötve. Én ezt ismerve, én T-éknek mindig mondtam, hogy nem szabad falun maradni." (középkorú édesanya, házas, 2 gyerekes, szakmunkás)

Kisebb boltok minden településen találhatóak, van azonban, ahol már friss pékáruért is a szomszéd faluba kell menni, posta a többségükben nincs, és orvos is csak hetente egy alkalommal rendel.

„Itt kocsi nélkül nem lehet meglenni. Pláne akinek kisgyereke van, idősebb vagy akármi, ha a mentő későn ér ki. A gyerekeket, kocsit fogadjon az ember, akinek nincsen. Úgyhogy ez nagyon rossz. Alig tudtam én is megszokni, hogy se posta, se orvos nincs, se gyógyszertár, semmi. Hogy a másik faluba, két faluval arrébb kell menni. Szörnyü." (középkorú édesanya, házas, 3 gyerekes, szakmunkás)

A vizsgált falvak munkaerőpiaci potenciálja abban rejlik, hogy mindegyik közel helyezkedik el valamilyen kisebb vagy nagyobb városhoz, ezért a kistelepülések többségének népessége sok esetben ingázik a közeli munkalehetőségek miatt. Akik a kistelepüléseken belül dolgoznak, jellemzően mezőgazdaságból élnek, vagy az önkormányzatok közmunkaprogramjaiban dolgoznak. Előfordul olyan falu is, ahol a munkaerő nagy része közfoglalkoztatott és olyan kistelepülés is, ahol vannak helyi munkáltatók, így a munkaképes lakosság egy része el tud helyezkedni intézményekben, fejlesztési projektekben, kisebb-nagyobb cégeknél vagy helyi vállalkozásokban. Kedvező jellemzőként tekinthetünk még a falvak alacsony ingatlanáraira, amely vonzó tényező lehet a kisebb városok közelében, ezeket a költségeket a megkérdezettek közül is többen mérlegelték akkor, amikor a maradás mellett döntöttek.

„Másrészt pedig pedig ö... az ingatlanárak alacsonyak ö... a faluban, tekintve egy nagyvároshoz mérten." (fiatal nö, párkapcsolatban él, diplomás)

A falvak természetes szaporodása enyhe emelkedést vagy stagnálást mutat, csak egy-két faluban észlelhető jelentősebb fogyás, de ezekben sem haladja meg a 15 ezreléket (2015-ös adat). A falvak felében pozitív a vándorlási egyenleg (ezrelékben értelmezve), az elvándorlók számánál magasabb az odavándorlók száma (KSH 2018). Ahol negatív az egyenleg, ott sem túl magasak az arányok, -1 és -11 ezrelék (2015-ös adat) között mozognak (KSH 2018). A roma kisebbség aránya az érintett községek többségében magas, de előfordult olyan falu is, ahol csak 1-2 roma szár- 


\section{TEMATIKUS TANULMÁNYOK - Községekben élő immobil fiatalok}

mazású család él. A településeken belüli arányuk folyamatos emelkedését azonban többször kiemelték a megkérdezettek.

„Egyre többen járnak el dolgozni, egyre nagyobb a munkanélküliség és régen ugye nem volt kisebbségi önkormányzat most ugye már kellett, hiszen egyre több a roma származású ember." (fiatal férfi, egyedülálló, diplomás)

Az elmondottak alapján a vizsgált falvakban jelentősebb konfliktusok a nem roma és a roma származásúak között nem érzékelhetők, alapvetően békés együttélésekről beszélhetünk, amihez a falvak felében cigánytelepi szegregáltság párosul.

„Hát hogyha most, ugye ki merek mondani mindent, megmondom neked öszintén egyre több a cigány, amivel nem tudunk mit kezdeni. Nekem semmi gondom nincsen velük, aki dolgozik... Most is dolgozik nálunk hetvenegy vagy hetvenhárom ember, nem tudom most pontosan, mert változik nap, mint nap a létszám. És ezzel semmi gond nincsen..."(fiatal férfi, egyedülálló, érettségizett)

\section{A szülők társadalmi helyzete}

A szülőkről általánosságban: korukat tekintve átlagosan 50 év körüliek, előfordult azonban 41 és 64 éves szülő is, egyaránt vannak édesanyák és édesapák is az interjúalanyok között. Iskolázottságukat tekintve a legtöbben szakmunkás végzettségüek, a legmagasabb végzettségű szülő érettségivel rendelkezik, és van 3 osztályt végzett is közöttük. Etnikai hovatartozás alapján a többség nem roma származású, de van roma származású interjúalany is. Egyetlen szülő egyedülálló, a többiek házasságban élnek. A gyerekek száma 1-től 5-ig terjed, a legtöbb szülőnek 2 gyereke van (természetesen ebbe minden született gyerek beleértendő, nem csak a 18 év alattiak). A szülők többségének munkaerőpiaci helyzetük alapján aktív, előfordul háztartásbeli és egyetlen megkérdezett közfoglalkoztatott. Az érintett fiataloknak legalább az egyik szülője biztosan dolgozott, a legtöbbjüknek mindkettő.

„Hát szerintem nem jobb, mint a többinek, hát hogy mondjam. Mivel én dolgozni járok, meg azért sokan járunk a családból dolgozni. Jó a fiatalok azok a maguk karrierjéért, a családjuknak kell kiépítéséért kell járni dolgozni. De biztos, hogy jobb helyzetben vagyok, mint aki a közmunkára jár dolgozni a faluba, akik azért elég sokan vannak. Ez nem csak az anyagi vonzata miatt, hanem kimozdul az ember, nem szúkül be az agya, többet tud a világról. Most nem csak a pénzről beszélgetünk minden esetre. Hanem nem szúkülök be." (középkorú édesanya, házas, 2 gyerekes, szakmunkás) 


\section{TEMATIKUS TANULMÁNYOK - Községekben élő immobil fiatalok}

A szülők munkamobilitása alacsony szintű, csak kevesen vállalnak közülük meszszebb jövedelemszerző tevékenységet.

„Igazából aki teheti, nem nagyon akar elmenni még Nyíregyházára se dolgozni. Inkább mindenki közelebb akar. Az már nagyon merész, aki Nyíregyházára elmegy dolgozni." (középkorú édesapa, házas, 2 gyerekes, szakmunkás)

Lakóhelyeik bemutatása során két tényezőt emeltek ki, az egyik, hogy ezeken a kistelepüléseken nőttek fel, ragaszkodnak hozzá, a másik pedig a falu értékei, mint például a csendes és szép környezet, hogy mindenki ismer mindenkit, valamint a falusi nevezetességek, értékek.

„Hát mert ide születtem és én már ide szoktam, itt van az életem, itt van mindenem. Nem tudnék elmenni másfelé."(középkorú édesanya, egyedülálló, 5 gyerekes, 8 általános)

„Szép a környezetünk, erdők, hegyek vesznek körül bennünket. Vannak nevezetességeink." (középkorú édesanya, házas, 2 gyerekes, érettségizett)

Voltak olyan szülők is, akik viszont nem szeretnek a településén élni, ennek okai között említették a falvak zártságát, a kimozdulási lehetőségek hiányát, az infrastrukturális hátrányokat és a munkaerőpiaci lehetőségek korlátozottságát.

„52 évesen azért eljutottam ide, hogy nem jó itt lakni... Elöször, mondjuk én szerettem gyereknek, mondjuk szabadabb volt az élet, mint bármerre. De 52 évesen eljutottam oda, hogy nem szabad falun maradni." (középkorú édesanya, házas, 2 gyerekes, szakmunkás)

A falvak történelméről való beszélgetések során minden esetben előkerült a termelőszövetkezet mint elsődleges foglalkoztató. A szülők minden esetben pozitívan tekintenek vissza ezekre a szervezetekre, amelyek egyben helyben maradásra is ösztönözték a lakosságot a rendszerváltás előtt.

„Mindenkinek meg volt, úgy mondjam a TSZ felbomlása az nagyon nagy hátrányt okozott az embereknek, végülis kialakult akkor egy kert, mindenkinek volt egy kis földje, nem kicsit, hát kinek mennyi járt a TSZ világból. És akkor mindenki gazdálkodott, úgy mint a mi világban, meg van müvelve minden darab föld. Úgy mint nekünk is volt káposzta, karfiol, annak idején, mikor ide kerültem, 20 évvel ezelött. Úgyhogy mindenki megmüvelte magának a kis földet, el tudta adni a kis portékáját, úgy, ahogy. Valahogy megéltek belóle az emberek." (középkorú édesapa, házas, 2 gyerekes, szakmunkás) 


\section{TEMATIKUS TANULMÁNYOK - Községekben élő immobil fiatalok}

„Az építőiparban dolgoztak a férfiak, akik eljártak. Akik itt maradtak a TSZben dolgoztak, mezőgazdaságban, állattartásban is foglakoztak... Hogyne lett volna. Paradicsomot, almát, gyümölcsöt termesztettek. Juhokat, tehenet tartottak. Már nincsenek jelen, mert a TSZ is megszünt, már még állattartás se nagyon van a faluban." (középkorú édesanya, egyedülálló, 5 gyerekes, 8 általános)

A rendszerváltás után a vizsgált falvak többségében megszűnt a mezőgazdasági termelés, igaz, előfordul közöttük olyan település is ahol ma is sokan foglalkoznak még mezőgazdasági termeléssel. Ezek mellett bizonyos falvak földrajzi helyzetükből adódóan történetileg mobilnak mutatkoztak, bányavárosok közelében, ipari létesítmények határában helyezkedtek el, ezért a lakosság egy jelentő része ápol mobilitási hagyományokat.

„- Dolgozni? Dolgozni a bányákba. A környező bányákba, a Borsod Chem, a bányákhoz tartozó ilyen kiszolgáló egységekhez, könnyü betonba, a habselyembe, a TSZ-be...

- És hova? Milyen messzire?

- Hát ilyen... Fekete völgy volt a legmesszebb azt hiszem. A fekete völgy, Ózd, Putnok, Ragály. Ebbe a körzetbe. De föleg Barcikára." (középkorú édesanya, házas, 2 gyerekes, szakmunkás)

A rendszerváltást követően véget értek a mobilitási és megélhetési lehetőségek az érintett falvak többségében, alternatívaként megjelent néhány foglalkoztató és a közfoglalkoztatás.

„Hát itt nincs semmi, még jobban nincs. Pláne, hogy bezárt a bánya. Meg már nincs TSZ. Már nem tudnak hova menni dolgozni. Közmunka.” (középkorú édesanya, házas, 3 gyerekes, szakmunkás)

A falvak történelmére, tradícióira vonatkozó kérdések kapcsán a szülők egy része ugyanarra a következtetésre jutott, nevezetesen, hogy támogatják gyermekeik elmenetelét, nem látnak gyerekeik számára jövőt a falujukban.

„Munkalehetöségek terén: lett a közfoglalkoztatási program, de ezen kívül semmi nincs már itt. Régen azért mindenki megtalálta a munkát. Voltak napszámok meg segédmunkák és sokan inkább ebbe dolgoztak. A fiatalok lehetôségei terén: Azon semmi. A fiataloknak el kell innen menni, mert itt nem találnak munkát. Akinek van esze és tanul, az menjen elfele innen nagyobb településekre." (középkorú édesanya, egyedülálló, 5 gyerekes, 8 általános) 


\section{TEMATIKUS TANULMÁNYOK - Községekben élő immobil fiatalok}

A családról szóló kérdések kapcsán a szülői interjúkban arra voltunk kíváncsiak, hogy a fiatalok családjában, rokonsági körében vannak-e követhető mobilitási példák, mobilnak tekinthető-e a család. Ebben a dimenzióban sem rajzolódik ki egyetlen irány a falujukat lehetőségként megélő fiatalok szüleinek válaszai alapján. Vannak tipikusan mobilnak tekinthető családok, mint például az olyan család, ahol az édesanya vagy az édesapa külföldön dolgozik.

„Szúkebb, tágabb családból? A feleségem kint dolgozik Ausztriában, valami szállítási cégnek valamilyen vezetője." (középkorú édesapa, házas, 1 gyerekes, szakmunkás)

A családok másik része nem mutat mobilitásra hajlandóságot, és a közelmúltban sincsenek erre pozitív példával szolgáló családtagok.

„- Mennyire lett az ilyen elköltözés később jellemző a családban?

- Semennyire. Szerintem félnek megmozdulni a fiatalok, el vannak itt kényelmesedve. Anyu meg apu eltart mindenkit... a bátyám járt el, messzebbre egyedül mert a közelben nem kapott munkát, de a legtöbben a TSZ-ben dolgoztak. Hát, ez annyira nem volt jellemző egyáltalán." (középkorú édesanya, egyedülálló, 5 gyerekes, 8 általános)

A szülők kapcsolathálói elsősorban a települések méretéből adódóan a falvak lakosságára koncentrálódnak, ezen belül a szülők többségét ismerik a faluban. Külön megbecsültségnek örvendenek a településeken belül azok a szülők, akik valamilyen helyi intézményben dolgoznak, több megkérdezett fiatal édesanyja volt ilyen helyzetben a saját faluján belül.

„Hát én úgy gondolom, hogy az emberek itt ismerik egymást, mert nem nagy településrôl beszélünk, engem is hiszen gyerekek között vagyok és ezáltal, a szülőkön keresztül sokan ismernek." (középkorú édesanya, házas, 2 gyerekes, érettségizett)

A falun kívüli kapcsolata csak kevés szülőnek van, elsősorban azoknak, akik más településen dolgoznak, vagy máshol tanultak fiatalabb korukban és megmaradt az ismeretségük. A vizsgált fiatalok szülei között ilyenekből volt a legkevesebb.

„Hát a falun kívül... hát nem nagyon megyek a faluból ki, mert én jobban itthon vagyok, kislyányom. Hát én nem nagyon megyek ki." (idös édesanya, házas, 4 gyerekes, 3 osztályt végzett) 


\section{TEMATIKUS TANULMÁNYOK - Községekben élő immobil fiatalok}

„Falun kívül is vannak. Országos szinten vannak kapcsolataim.” - munkája miatt (középkorú édesapa, házas, 1 gyerekes, szakmunkás)

A szülőket kérdeztük gyerekeik iskoláztatásáról, válaszaik alapján a szülők fele saját maga döntött gyereke iskoláztatásáról, hová menjen, mit tanuljon, míg a szülők másik része jellemzően a gyerekeire bízta, amiben tudták pedig támogatták őket a továbbiakban.

„Igazából feleségem azért sok mindennek utána járt, hogy azért, van egy két ismerôs, hogy akkor na mék iskola milyen. Első inkább az volt, hogy mék iskola milyen, na hát ő kiderítette, hogy mék iskola milyen. És akkor úgy, onnantól kezdve ugye szakma az már megvolt, azt is kibeszéltük, hogy mi legyen, és akkor az iskolaválasztásban az volt inkább a lényeg, hogy megnéztük, hogy milyenségben meg minőségben azért az iskolák milyenek." (középkorú édesapa, házas, 2 gyerekes, szakmunkás)

„Hát azt csinálják, amit ők akartak. Én nem szóltam bele. Tanulják azt, amit akarnak, olyan szakmát tanuljanak, ami érdekli ôket. Most ha azt mondtam volna, hogy te menjél ide oszt nem szereti, akkor úgyse csinálja végig." (középkorú édesanya, egyedülálló, 5 gyerekes, 8 általános)

A továbbtanulás sokszor anyagi nehézségeket jelentett a falusi családok számára, mivel már középfokú vagy szakirányú végzettség megszerzéséhez is másik településre kellett, hogy küldjék gyereküket.

„Igen jelentett. Egyrészt, hogy hogy fognak beilleszkedni, másrészt pedig, aggasztott az is, hogy anyagilag, hogy tudunk megfelelni az elvárásnak." (középkorú édesanya, házas, 2 gyerekes, érettségizett)

A fiatalokra irányuló jövőképükről, céljaikról, vágyaikról is kérdeztük a szülőket. Ebben a dimenzióban is megoszlottak a vélemények, voltak, akik erőteljesen képviselték és hittek gyermekeik faluban maradásában, ebben látják jövőjüket. Ezeknek a szülői véleményeknek erős a megtartó hatása, befolyásolhatják és magyarázhatják gyermekeik döntéseit is, illetve a kistelepülésen maradást lehetőségként, perspektívaként megélést is.

„Ide köt minket minden, a családot. Amit édesapám itt felépített dolgokat. Tényleg teljesen mindent, egzisztenciát, kapcsolati tőkét, ilyesmit. És most hogyha ezt felrúgja az ember, akkor utána máshol majd építsen ki megint egyet? Ez így a legegyszerübb megoldás szerintem." (középkorú édesapa, házas, 1 gyerekes, szakmunkás) 


\section{TEMATIKUS TANULMÁNYOK - Községekben élő immobil fiatalok}

A szülők egy másik csoportja azt gondolja, hogy a kistelepülésen nincs jövője gyerekeiknek, ezért ösztönzik gyereküket a mobilitásra.

„Hát az biztos, hogy ne itt éljenek, mennyjenek másfele és olyan dologgal foglalkozzanak, azt csinálják, amit szeretnek... Hát én azt mondom, menjenek innen, mert itt nincs élet. Mindig mondom nekik, hogy ne ragadjanak le itt, mint én anno." (középkorú édesanya, egyedülálló, 5 gyerekes, 8 általános)

Vannak, akik pedig elmondásuk alapján a gyerekeikre bízzák a döntést.

„Hát nagy terveim nem voltak, úgy voltam vele, hogy majd ők eldöntik, ha itt maradnak velünk, akkor támogatom öket abba is, de ha el akarnak menni messzebb esetleg abban is támogatom öket." (középkorú édesanya, házas, 2 gyerekes, szakmunkás)

A szülők saját maradásukról egyöntetűen nyilatkoztak, a család közelsége, a megszokás, a település szeretete, megfelelő munkahely és a családi ház indokolja a maradásukat.

„Hát szerintem a családom az ragaszkodik úgymond a szülöföldjéhez, a barátokhoz, családhoz és talán ez a legnagyobb ok, hogy itt maradtunk." (középkorú édesanya, házas, 2 gyerekes, érettségizett)

„Itt van mindenünk kész. Én már nekem azaz idő, ami hátravan, nem tudom, kinek mennyit szabnak, én nekem az már... én már nem akarok belefogni másba. Ez már megvan, ezt kell megőrizni. Nem. Igazából nem tervezem, hogy még az utolsó 20, vagy 40, vagy 30 évet még azzal foglalkozzak, hogy még építsem magamnak, meg... nem. Ez már megvan, ezt kell megőrizni. Ezt kell használni, kész." (középkorú édesapa, házas, 2 gyerekes, szakmunkás)

Találkoztunk olyan szülővel is, aki saját maradását kényszerként élte meg, aminek oka elsősorban az idős szülők ápolása, gondozása. Ezt azért emelném ki, mert jelenthet példát a fiatalabb generációk számára, akik a szülő megöregedésével szintén dönthetnek hasonló okok alapján a falujukban maradás mellett.

„-De jobban én is azért hajlottam, pedig jobb munkahely szempontjából, hogy nem bejárós az ember. Az sokat jelent. Azt hiszem, hogy valaki maradjon a szüleim mellett.

- Mert mindenki más elment?

- Igen, mindenki más." (középkorú édesanya, házas, 2 gyerekes, érettségizett és szakmunkás) 


\section{TEMATIKUS TANULMÁNYOK - KöZségekben élő immobil fiatalok}

\section{A sikeres falusi fiatalok immobilitásának okai és jövőtervei}

A falvakat lehetőségként értelmező, az ott maradásban perspektívát látó fiatalok iskolai végzettsége a legmagasabb. A legtöbb diplomás ebbe a típusba sorolható. Mindegyik fiatalnak van munkája, többségük esetében a településükön belül, de van, aki vagy (1) a közeli kisvárosba jár át dolgozni,

„21 éves vagyok. Ny-án születtem, itt lakok T-en, a polgármesteri hivatalban dolgozok, mint pénzügyes."(fiatal férfi, egyedülálló, érettségizett, dolgozik)

vagy (2) elsősorban a szakmunkások helyben és a környező településeken látnak el szakmunkákat,

„21 éves vagyok a helyi általános iskolában végeztem, aztán a szomszéd településen letettem a festő szakmát, belekezdtem a mezőgazdasági szakmába is, de félbehagytam munka miatt. Most dolgozom festőként." (fiatal férfi, egyedülálló, szakiskola, dolgozik)

és van, aki (3) mezőgazdasági termelésből él, fiatal gazdálkodó.

„M-ra jártam, ipariba. ott egy hegesztőt végeztem el, mai napig abban dolgozom, már 3 éve. Mellette méhészkedünk, amit itthon folytatunk. hát végül is családi gazdaságban. Már így maradt részben rám, mert júliusban nyertem fiatal gazda pályázatot, és akkor most ez irányban fogunk elmenni. Az elkövetkezendő időszakban." (fiatal férfi, egyedülálló, szakmunkás, dolgozik)

A fiatalok helyzete munkaerőpiaci szempontból előnyösnek tekinthető, figyelembe véve a falvakra és környékükre jellemző magas munkanélküliségi arányokat és a beszűkült munkaerőpiaci lehetőségeket. Már ez önmagában magyarázatot jelenthet arra, hogy ezek a fiatalok lehetőségként tekintenek falujukra.

A falujukról alkotott véleményeik alapján a fiatalok többsége alapvetően pozitív képet fest saját kistelepüléséről, szeretnek a településen élni, elsősorban a falubeliek, a gyerekkor és a család miatt, vagy előfordult, hogy a településhez kötődő szabadidős tevékenységeik miatt. Volt, aki a fővárossal összevetve is a faluja előnyeit hangsúlyozta. Találkoztunk azonban olyan fiatallal is, aki annak ellenére, hogy lehetőségként tekint a kistelepülésre, alapvetően nem szereti, nincs jó véleménye saját falujáról.

„Hú, nem jó itt lakni, mert itt semmi kitörési lehetőség sincs. Mondjuk én nyilván jól jártam anno, amikor bekerültem a konyhára... De a mai fiataloknak 


\section{TEMATIKUS TANULMÁNYOK - Községekben élő immobil fiatalok}

nincs kitörési lehetőségük és nem jó itt lakni... Nagyon sok a pletykás, mindenki a másikat nézi meg." (fiatal nő, egyedülálló, érettségizett, dolgozik)

Az interjúban tovább sorolja a kistelepülés összes hátrányát, a hiányzó lehetőségeket, az elmaradottságot, a bezártságot. Korábban idéztük az édesanyját, aki hasonlóan vélekedik falujukról, és a fiatalokról azt gondolja, hogy inkább nem mernek elmenni a kistelepülésekről. A fiatalok többsége viszont a lehetőségek növekedéséről és a falusi élet pozitívumairól mesélt.

„Hát itt nôttem fel, gyerekkoromat itt töltöttem. Szeretek itt lenni. Közel van a Hernád, imádok horgászni." (fiatal nő, egyedülálló, diplomás, dolgozik)

„Tehát ha sétálok az utcán, bárkinek köszönhetek, le áll velem beszélgetni. Érdeklődnek egymás után. Én ezért szeretek itt élni. Már most egyre több lehetőség nyílik a gyerekek részére is." (fiatal nő, házas, érettségi és OKJ, dolgozik)

A települések történelméről, a rendszerváltás előtti munkalehetőségekről a fiatalok egy részének nincs információja, azok, amiket hallottak, voltaképpen a termelőszövetkezetekre korlátozódnak, és az ezekkel kapcsolatos helyi mezőgazdasági munkákra. Egy-két fiatal viszont a saját szüleinél is mélyebb információkkal rendelkezett a korszakról.

„A régi B. tsz-be, itt a település szélén volt. Amit még tudok, hogy volt egy téglagyár, oda jártak dolgozni. Volt a 70-es évek közepéig egy gőz üzemú szivatytyútelep, ott volt nagyon sok munkás. A többiek azok pedig vagy I-ba, vagy Ny.-ra jártak, ami ilyen nagyobb vonzáskörzet volt." (fiatal férfi, egyedülálló, érettségizett, dolgozik)

Családjuk hagyományaiban keresve a mobilitási mintákat, csupán két fiatalnál van a szűkebb környezetében is mobil családtag, a többségnél azonban vagy nincsenek, vagy a tágabb rokonsági körben találtunk, akik viszont jelentősebb befolyásoló erőt nem jelentenek a fiatalok életébe, döntéseibe. Kérdeztük őket az elmenőkről, szerintük miért döntöttek a mobilitás mellett, ezzel kapcsolatban elsősorban a munkahelyek miatti vándorlást nevezték meg.

„Hát mindenképp a megélhetés. Gondolom a munka miatt vagy hogy könynyebb munkába bejárni teszem fel Ibrányból a buszjárat miatt is. Vagy a lakhatás miatt. Mert ugye aki innen elment annak vagy a szülei éltek itt, de már nem élnek vagy mindenképp ez, hogy a munka az, ami elvitte óket." (fiatal nö, egyedülálló, érettségizett, dolgozik) 


\section{TEMATIKUS TANULMÁNYOK - Községekben élő immobil fiatalok}

A családi együttélési mintáinak vizsgálata azt mutatja, hogy a fiatalok legnagyobb része a saját szüleivel él, vannak, akik kiterjesztett családokban, nagyszülőkkel, vagy az egyik szülő testvérével és annak családjával, és van olyan fiatal is, aki egyedül él vagy már saját családja van. Családjukat a fiatalok a településükön élőkhöz képest átlagosnak vagy átlag feletti életszínvonalúnak érzékelik, többségük a szülők és/ vagy saját maguk munkaerőpiaci helyzetével indokolja ezt.

„Életszínvonal, hogy van munkahelyünk, aki dolgozik annak. Mert a településnek a nagy része az vagy közmunkán él, vagy munkanélküli segélyen. És megtehetjük azt, hogy van gépjármüvünk, mindenkinek saját. Van áram, víz a lakásban, mert sok embernek az sincs. Hát így ennyi, amit tudok mondani." (fiatal férfi, egyedülálló, érettségizett, dolgozik)

„Hát szerintem annyiban más, hogy én találtam egy biztos munkahelyet másokhoz képest, akiket mondjuk az önkormányzat foglalkoztat és megkapják azt a bért, amit. Én szerintem attól egy picivel jobb helyzetben vagyok." (fiatal nö, egyedülálló, érettségizett, dolgozik)

Volt olyan fiatal is, akinek családi helyzete a falun belül hátrányosnak mondható, roma származásúak, azonban egyetemet végez, és jövőjét a helyi intézmények valamelyikében képzeli el, elsősorban a település szeretete és a családja miatt.

„Itt él a családom, itt élnek a szüleim, itt nőttek fel, mindenkit ismerek. És nagyon sok újítás is történt. Például az általános iskolát, ö... a tornatermet, a templomot, a buszmegállót, a tüzoltóságot felújították, ami számomra és a leendő munkahelyem szempontjából fontos." (fiatal nő, párkapcsolatban él, érettségizett, dolgozik és tanul)

A fiatalok kapcsolathálója összetett, a családokkal és a rokonokkal a többség helyben tartja a kapcsolatot, leginkább személyesen. A barátaikkal, ismerőseikkel általában az interneten, telefonon keresztül, mivel sokuknak a tanulmányok ideje alatt alakultak ki ezek a kapcsolatok, így leginkább távolabbi településekhez kötődnek. Akiknek szomszéd városokhoz, községekhez kötődnek a baráti kapcsolatai, azokkal alkalmanként együtt járnak el szórakozni. A falubeliekkel ismerik egymást, de ezek a kapcsolatok csak felületesek.

„Hát engem látásból nagyon ismernek, egyébként semennyire nem ismernek, ugyan ez igaz fordítva is. Nagyon sok ember ismerek én is, de közelröl elég kevés emberrel tartom a kapcsolatot." (fiatal férfi, egyedülálló, diplomás, dolgozik) 


\section{TEMATIKUS TANULMÁNYOK - Községekben élő immobil fiatalok}

„Inkább a falun kívül, mert ők többen vannak és komolyabbak.”(fiatal férfi, élettársi kapcsolat, diplomás, dolgozik)

Kérdeztük a fiatalokat a családjuk és saját maguk megítéléséről, elismertségéről a faluban. A fiatalok jelentős része a szülei által kivívott elismertséget tekinti meghatározónak saját elismertsége kapcsán. Voltak, akik a munkájuk miatt gondolják magukat elismertnek, és olyanok is, akik egyáltalán nem gondolják magukat elismertnek a kistelepülésükön.

Iskolai mobilitásuk a szüleikhez képest felfelé irányuló, a fiatalok legmagasabb iskolai végzettsége magasabb, mint a szüleiké, vannak közöttük olyanok is, akiknek édesanyjuk 3 osztályt végzett, a lánya pedig jelenleg egyetemista. A közép- és felsőfokú végzettségekhez minden esetben társult egy földrajzi mobilitás is. A szakiskolákért és gimnáziumokért általában a közeli kisvárosokig kellett utazni, míg a felsőfokú végzettséghez több mint 100 kilométert is megtettek a fiatalok. Akiknek nem kellett olyan nagy távolságokat utazniuk, azok inkább vállalták az ingázást, ez megnyugtatás volt a szülőknek és a fiatalok számára is biztonság, még akkor is, ha a tömegközlekedés sosem volt egyszerű a települések között.

„Mindig busszal jártunk. Putnok se volt messze, csak ugye ott rosszabb volt a közlekedés. Mert innen Galgócról Putnokra egyenesen nem megy busz. És akkor sokszor úgy kellett mennem, hogy elmentem reggel Vadnára. Vadnán vártam és akkor egy ózdi busszal vagy egy putnokival tovább mentem. Egyik sem volt olyan nagyon messze. Tehát én nem jártam Miskolcra, Pestre, ilyen helyekre. Úgyhogy egyik sem volt messze. Egyedül Putnokról volt a hazajárás kicsit nehezebb, mert általában mindig úgy végeztem az iskolában, hogy gyalogolnom kellett az elágazástól." (fiatal nő, házas, érettségi és OKJ, dolgozik)

Volt olyan fiatal is, aki kipróbálta a kollégiumot, azonban nem érezte jól magát, így bejáróssá vált, amit a szülő sokszor mélyebben élt meg.

„A lányom elment egyetemre, hogy ne kelljen neki bejárnia, azért minden nap Miskolcra az egyetem mellett. Bement kollégiumba. És mikor mentem a kollégiumba én sírva fakadtam, olyan a kinézete. Az én lányom nem úgy volt hozzá szokva az itteni élethez, hogy közös fürdöszoba stb., stb., stb. Meg egy folyóson a fiúkkal. Én nem úgy neveltem a gyerekemet. És 3 hónap után nem igazán jók voltak, 1 hónap, 3 hónap után nem igazán. Jött haza mindig a lányom hétvégén. És mindig mondta, hogy nem jó anya, rossz tanulni stb., stb., stb. És mondtam neki, hogy figyelj gyerek, ha nem sikerül, akkor hagyd abba a kollégiumot és gyere haza. És akkor próbáltuk, így hogy bejárós legyen." (középkorú édesanya, házas, 2 gyerekes, érettségizett) 


\section{TEMATIKUS TANULMÁNYOK - Községekben élő immobil fiatalok}

A fiatalok többsége a végzettség megszerzéséhez kötődő mobilitásra jó emlékként tekint, többen életük legjobb éveiként beszélnek arról az időszakról.

„Igen azt elöbb félre mondtam, kollégiumban 5 évig laktam az fantasztikus volt, szerintem az kihagyhatatlan egy diák életéből. Legjobb barátságok ott is kötődnek meg fantasztikus élményekkel gazdagodik az ember a kollégiumi évek alatt. Egyetem alatt albérletben laktam." (fiatal férfi, egyedülálló, diplomás, dolgozik)

Ahogy azt a szülők interjúinál már megjegyeztük, gondot elsősorban anyagilag jelentett a gyerekeik iskoláztatása, olyan szintű aggódást nem érzékeltünk, ami miatt ne engedték volna el őket távolabbi településekre tanulni. A megkérdezett fiataloknak tehát vannak mobilitási tapasztalataik, többségüknek hosszabb távú is, amik elsősorban az iskoláikhoz kapcsolódnak.

Munkatapasztalataik a tanulmányi idő alatt a fiatalok többségének nem voltak, de volt közöttük olyan, aki saját magának, zsebpénz miatt vállalt munkákat, és olyan is, akinek muszáj volt a tanulmányok finanszírozásában segítenie a szüleinek, ezért vállalt el diákmunkákat. Jelenlegi munkáik, amint azt már korábban említettük, a településekhez kötődnek, van a fiatalok között mezőgazdasági adminisztrátor, pályázati referens, konyhai kisegítő, testnevelő tanár, gazdálkodó, pénzügyi előadó és szobafestő is.

Az egyetemistáknak a tanulmányaik alatt volt lehetőségük külföldi mobilitási programokban is részt venni, a többiek közül is van, aki nyaralás, kirándulás vagy nyári munka céljából szintén eljutott másik országokba. Összességében tehát a mobilitási lehetőségek és tapasztalatok terén nincsen elmaradása a megkérdezett fiataloknak.

A félelmek az ismeretlentől, idegentől kérdésekre a fiatalok válaszai általában a magabiztosságról és az önállóságról tanúskodtak, nem számoltak be jelentősebb negatív érzésekről a távolléteik miatt. Kudarcélményről egyetlen interjúalany sem beszélt.

„Ez nem igazán fordult elő. Manapság már rugalmasan mozgok, köszönhetöen az 1 éves külföldi tapasztalatoknak is. Kezdetben édesanyámék nagyon féltettek, már hogyha csak a falun kívül is elkerültünk, vagy bárhova mentünk nagyvárosba. De szerencsére megtanulták, hogy mindig visszatérünk, és nem esett semmi bajunk testvéremmel." (fiatal nő, párkapcsolatban él, érettségizett, dolgozik és tanul)

Honvágyat és hiányérzetet több fiatal is érzett távolléteik kapcsán, ezt az egyik lány fogalmazta meg talán a legkifejezőbben, aki nyári munkája során élte ezt át. 


\section{TEMATIKUS TANULMÁNYOK - Községekben élő immobil fiatalok}

„Hát igen mondjuk, mikor kint voltam Menorkán, akkor eszembe jutott. Mikor már több hónap után, hogy hát, de jó lenne egy töltött káposzta vagy nem is tudom mi. Ebbe benne volt úgy a család is. Akkor. De ilyen rövidebb idók alatt nem éreztem, azt, hogy hiányozna. Nyilván, ha már egy hónap eltelik, akkor már fú... Nálam akkor kezd." (fiatal nő, egyedülálló, diplomás, dolgozik)

Kértük, hogy meséljék el a fiatalok egy „sikertelen” és egy általuk „sikeresnek” ítélt személy történetét, példát arra, aki nem tudott elhelyezkedni máshol és hazatért és egy olyat, aki elment és jól érzi magát máshol. Az elsőre kevesebben tudtak példát, a kudarcos mobilitásra azonban szinte mindegyik fiatal. Egy negatívnak tekinthető példa:

„Így konkrét személyre nem tudok rámondani vagy nevet, vagy konkrét személyt mondani, de volt olyan, aki elindult Németországba, hogy majd ó esetleg ott talál munkát és majd ő ott fog dolgozni, aztán nem sikerült. Kint töltött napokat semmi nélkül aztán hazajött. Mert ugye nem talált munkát vagy nem tudott megállapodni." (fiatal nő, egyedülálló, érettségizett, dolgozik)

Egy pozitív példa:

„Persze tudok ilyet. Szembe szomszédunk is már eljutottak Sopronig. Ők jól érzik magukat, vagy akár unokatesómék, vagyis bátyámék, ők egész Angliáig, nagyon bevált." (fiatal férfi, egyedülálló, diplomás, dolgozik)

Az interjúkérdéssor végén feltettük azt az összegző kérdést, hogy szerintük összességében miért maradtak a falujukban. Néhány részletet kiemeltünk a válaszokból, amelyek talán jól összefoglalják a miértek sokszínűségét, de mégis szintézisét.

„Úgy gondolom, hogy idézőjelbe' van is rám kereslet, hiszen kevés a ö... diplomával rendelkező személy a faluban, illetve még van tanárhiány is jelenleg az iskolában." (fiatal nő, párkapcsolatban él, érettségizett, dolgozik és tanul)

„Hát egyrészt munka miatt egyrészt család miatt. Inkább mondanám véglegesnek." (fiatal férfi, egyedülálló, diplomás, dolgozik)

„-És volt-e már kudarc élményed, amikor távol voltál a falutól? Hogy valami nem úgy múködött, mint itthon?

- Én nehezen alkalmazkodok." (fiatal nő, egyedülálló, diplomás, dolgozik) 


\section{TEMATIKUS TANULMÁNYOK - Községekben élő immobil fiatalok}

\section{Összegzés}

A tanulmányban bemutattam azoknak az immobil fiataloknak a társadalmi jellemzőit, akik 2500 fő alatti kistelepülésen élnek, és lehetőséget, perspektívát látnak a saját falujukban maradásra. Az első részben a részletes elméleti felvezető helyett a bevezető fő feladata a téma felvázolása és a belső vándorlások trendjeinek leírása volt. A kutatásban érintett települések mind az ország hagyományos elvándorlási térségeiből kerültek ki, 2018-ban, amikor a demográfiai mozgásokat látva a legnagyobb szerepük van a kistelepülések jövőjét, társadalmi struktúráját tekintve azoknak a fiataloknak, akik ott maradnak a falvaikban.

A módszertani fejezetben részletesen bemutattam a szülőkkel és a fiatalokkal készült interjúk dimenzióit.

A települések többsége társadalmi és gazdasági szempontból hátrányos helyzetű, valamint infrastrukturális és tömegközlekedési hiányokkal jellemezhető. A falvak munkaerőpiacát a környező nagyobb települések és azok elérhetősége, valamint a településen lévő néhány munkáltató és a helyben végezhető, leginkább mezőgazdasági munkák határozzák meg. A települések többségének jellemzője az idősek és a romák növekvő aránya.

A legtöbb szülő középfokú végzettségú, dolgozik, és többségük munkamobilitása alacsony szintű. A szülők kapcsolatai, néhány kivétellel, a kistelepülések lakosságára és néhány elköltözött rokonra korlátozódnak. Egy részük ösztönözné gyerekeit a vándorlásra, míg mások bíznak azok maradásában. Gyerekeik iskoláztatását a szülők támogatták, sokszor az anyagi nehézségek ellenére is. A megkérdezett fiatalok többsége vélhetően ennek köszönhetően magasabb iskolai végzettséget szerzett, mint szülei.

A településüket lehetőségként és perspektívaként megélő fiatalok között a közép- és felsőfokú végzettségúek többségben vannak, valamint a teljes mintán belül is a diplomások látnak a leginkább perspektívát falujukban. A fiatalok mindegyikének van munkája, ami sok esetben kapcsolódik lakóhelyükhöz, vagy annak közelében lévő kisvároshoz. A fiatalok többsége kötődik a településéhez, családi, baráti kapcsolatai, kialakult szokásai miatt. Félelmeik, rossz élményeik nincsenek a korábbi, otthonuktól való távollét kapcsán, többen voltak kollégisták, vagy laktak albérletben. Jövőjüket a továbbiakban is falujukban képzelik el.

\section{Irodalom}

Bálint L. - Gödri I. (2015): Belföldi vándorlás. In: Monostori J. - Őri P. - Spéder Zs. (szerk.): Demográfiai portré 2015. Jelentés a magyar népesség helyzetéről. http://demografia.hu/kiadvanyokonline/index.php/demografiaiportre/article/ view/2485/2483 (utolsó letöltés 2019.08.27.) 


\section{TEMATIKUS TANULMÁNYOK - KöZségekben élő immobil fiatalok}

Bálint L. - Obádovics Cs. (2018): Belföldi vándorlás. In: Monostori J. - Őri P. - Spéder Zs. (szerk.): Demográfiai portré 2018. http://demografia.hu/kiadvanyokonline/ index.php/demografiaiportre/article/view/2741/2629 (utolsó letöltés: 2019. 08.27.)

Dövényi Z. (2007): A belföldi vándormozgalom strukturális és területi sajátosságai Magyarországon. Demográfia, 50. évf. 4. sz. 335-359. o.

Hárs Á. (2012): Földrajzi mobilitás. A kereslet és kínálat összeegyeztetése. In: Scharle Á. (szerk.): Az eltűnt egymillió munkahely nyomában. Budapest Szakpolitikai Elemző Intézet. http://www.budapestinstitute.eu/uploads/foglpol20_5_ 1mobilitas.pdf (utolsó letöltés 2019.08.27.)

Központi Statisztikai Hivatal (2018): A belföldi vándorlás aktuális trendjei, 20122017. https://www.ksh.hu/docs/hun/xftp/stattukor/belfvand17.pdf (utolsó letöltés 2019.08.27.)

Massey, D. S. - Arango, J. - Hugo, G. - Kouaouci, A. - Pellegrino, A. - Taylor, J. E. (1993): Theories of international migration: A review and appraisal. Population and Development Review, No. 19. Vo. 3. 431-466. o.

Stark, O. - Bloom, D. (1985): The new economics of labor migration. American Economic Review, Vol. 75. No. 2.173-178. o. 